\title{
ASPEK-ASPEK TINDAK PIDANA DALAM PERBANKAN SYARIAH DAN KONVENSIONAL
}

\author{
Hamsir \\ Universitas Islam Negeri Alauddin Makassar
}

\begin{abstract}
The purpose of this paper is to observe, predict and assess the existence of Islamic banking in Indonesia in the development of facing and maintaining public confidence in the issue of banking crime that are currently, have been and will come. Sharia Bank As an institution in the form of a business / service industry, so in the future, commercial/state banks such as state-owned enterprise banks that manage Sharia Banks will be merged as separate National Sharia Banks. Space and opportunities for criminal acts in Islamic banking have the same space and opportunities as other banks (conventional banking). However, what distinguishes if a criminal act is suspected, it must involve institutions formed from the provisions in sharia banking law (national sharia board, sharia supervisory board) accompanied by the Police and financial service authority institutions, but in investigative work. The police apparatus or financial services authority first asks for instructions from the national sharia board and sharia supervisory board.
\end{abstract}

Keywords: Crime, Conventional Banking, Sharia Banking.

\section{Abstrak}

Tujuan penulisan ini, untuk mengamati, memprediksi dan menilai keberadaan perbankan syariah di Indonesia dalam perkembangan menghadapi dan menjaga kepercayaan masyarakat dari persoalan tindak pidana perbankan atau kejahatan perbankan yang saat ini, pernah dan atau akan datang. Bank (Syariah) Sebagai suatu institusi/lembaga dalam bentuk usaha/industri jasa (BUMN), begitu pun ke depan (wacana 2020) Bank-bank umum/negeri (BNI, BRI \& Mandiri) yang mengelola Bank Syariah akan dimerger sebagai Bank Syariah Nasional tersendiri ${ }^{1}$. Ruang dan peluang terjadinya tindak pada perbankan syariah memiliki ruang dan peluang yang sama dengan perbankan lainnya (konvensional). Namun yang membedakan bila diduga terjadi tindak pidana di dalamnya, haruslah

\footnotetext{
${ }^{1}$ Tribun Online, Desember 2020.
} 
melibatkan lembaga-lembaga yang terbentuk dari ketentuan dalam hukum/perundang-undangan perbankan syariah (DSN, DPS) disertai institusi Kepolisian dan lembaga OJK, namun dalam kerja penyidikan aparat Polri atau OJK terlebih dahulu meminta petunjuk DSN dan DPS.

Kata Kunci : Perbankan Konvensional, Perbankan Syariah, Tindak Pidana.

\section{PENDAHULUAN}

Kegiatan bank sebagai pengelola perjanjian antar para pihak, baik perbankan berposisi sebagai pihak investor/kreditor dan masyarakat sebagai debitur, atau sebaliknya bank hanya berposisi sebagai pengelola jasa/pelayanan para pihak, kedua peran itulah selama ini dilakukan.

Kebaruan tulisan ini, karena terkait beberapa tahun terakhir ini (2020) trauma menyimpan uang di perbankan konvensional, berdampak perbankan syariah pun demikian, juga mengalami tingkat kepercayaan (trust) yang menurun. Beberapa seminar tentang perbankan, umumnya mengulas perihal perkembangan dan alasan tentang sejauh mana tingkat pesimisme dan optimisme tentang keamanan menyimpan uang di bank, seperti yang dikemukakan oleh beberapa pakar dan dunia perbankan. ${ }^{2}$

Diketahui bahwa, adapun secara teoretis aspek hukum yang mengitari dalam kehidupan perbankan adalah keperdataan, olehnya bila timbul persoalan hukum di antara para pihak, penyelesaian bukan pada wilayah pidana, tetapi pada wilayah perdata, namun karena dunia perbankan, khususnya perbankan (syariah) berfungsi sebagai industri jasa/pelayanan, hal mana peluang untuk timbulnya pelayanan berdampak/berakibat kerugian/hilangnya kepercayaan atas bantuan jasanya berupa tanggung jawabnya, orang atau person/manusia sebagai pelaku pengelola, terkadang ingin atau sengaja/niat mengabaikan tanggung jawabnya dengan cara untuk mengambil untuk memiliki kepunyaan orang di bawah tanggung jawabnya, maka besar peluang/kemungkinan ada aspek pidana, antara lain perbuatan penggelapan (KUHPidana) pasal 372, 374, 378 atau pidana penipuan (KUHPidana) dan bentuk-bentuk kejahatan lainnya.

Ruang/sekat antara perdata dan pidana, memanglah teramat tipis, ibarat dipisahkan benang, bahkan perangkat teknologi salah variabel penting dalam pengelolaan perbankan, sehingga ada sebagian masyarakat awam, bagi mereka yang bermasalah dengan perbankan kemungkinan mengabaikannya dengan alasan rumit/ruwet untuk diketahuinya, sehingga sebagian masyarakat itu merasa itu adalah takdir yang menimpanya, para intelektual/pakar Islam, menyebut

2 Diskusi virtual "Purbaya”, 11 Desember 2020. Tentang Mengembalikan kepercayaan publik industri jasa perbankan.

81 
orang/masyarakat tersebut menganut paham/aliran (Jabariah), selain itu, ada pula orang/masyarakat yang lemah atau dilemahkan terhadap aturan atau sistem dalam perjanjian perbankan (perjanjian baku) lalu ada yang merasa rugi (khususnya pihak masyarakat) namun mereka menerima begitu saja, malas untuk mencari tahu kerugian itu, karena merasa rumit/ruwet atau karena dirumitkan sehingga orang/mereka tersebut tidak lagi mempersoalkannya,

Namun bagi mereka yang beraliran melawan takdir (Qodariah), tentunya akan mempersoalkan kerugian tersebut dengan segala keinginan tahunya untuk mengetahui secara detail tentang hak dan kewajibannya dalam perjanjian, sehingga perbankan harus menjawab dalam perspektif tanggung jawabnya secara rasional, obyektif. adil dan proporsional.

Hal-hal yang terjadi di atas secara hukum, bila ada perjanjian yang tidak memuat iktikad baik, biasanya ingin mengambil keuntungan yang berlebihan (irasional) terhadap seseorang yang tertera dalam isi/klausul perjanjian, maka yang merasa rugi dapat melaporkan ke Pengadilan dalam ranah perdata, adapun bila salah satu pihak merasa dirugikan atas perjanjian di luar yang disepakati dan membuat seolah-olah disepakati dengan cara membuat palsu/mirip kata/ucapan/pernyataan atau tanda tangan dalam suatu surat/dokumen perjanjian di bank tersebut, maka orang/masyarakat dapat melaporkan dulu otoritas perbankan (OJK) bila perbankan nasional dan biasanya kerja sama dengan pihak Negara Kepolisian (penyidik), dapat juga melibatkan penyidik kejaksaan, bila cukup bukti ( 2 alat bukti), maka dapat diteruskan dengan menahan sementara yang pelaku yang di sangka/diduga tersebut.

Kepolisian dan kejaksaan tentunya mempelajari dengan seksama dan sungguh atas pelaporan tersebut sebagai suatu tindak pidana, bila telah ditemukan minimal dua (2) alat bukti terjadinya tindak pidana.

\section{METODE PENELITIAN}

Penelitian ini dilakukan berdasarkan studi pustaka dengan berbagai referensi jurnal dan buku serta beberapa artikel terbaik dan terupdate. Penelitian Pustaka (library research) yaitu Penelitian dilaksanakan dengan mengumpulkan data dan landasan teoritis dengan mempelajari buku, karya ilmiah, hasil penelitian terdahulu, jurnal-jurnal terkait, artikel-artikel yang terkait serta sumber-sumber yang terkait dengan penelitian sesuai dengan penelitian yang diteliti. Setelah semua data telah diperoleh berhasil dikumpulkan selama proses penelitian baik data primer dan data sekunder dianalisis secara kualitatif kemudian disajikan secara deskriptif yaitu menjelaskan, menguraikan, menggambarakan 
permasalahan yang berkaitan dengan aspek-aspek tindak pidana dalam perbankan syariah dan konvensional.

\section{PEMBAHASAN}

\section{A. Ruang Dan Peluang terjadinya Tindak Pidana di perbankan Syariah}

Secara teoretis/normatif dogmatik, perbankan syariah tidak memungkinkan terjadinya tindak pidana, karena perbankan syariah lahir karena tuntunan dan tuntutan moral keagamaan berasaskan Quran dan hadis, untuk melahirkan sistem pengelolaan keuangan yang akan memakmurkan, menyejahterakan dengan prinsip-prinsip dan tujuan keadilan, kemanfaatan, keseimbangan, tolong menolong dan sebagainya.

Sebenarnya kalau ditelisik, risiko kejahatan pada perbankan syariah relatif kecil dibandingkan dengan perbankan konvensional, karena suasana, latar belakang, seseorang yang mengelola perbankan syariah dianggap telah memiliki track record, kepribadian keimanan, ketakwaan. moral kepada diri (kejujuran) dan akhlak moral kepada orang lain (moral responsibility) yang dapat menahan bankir itu melakukan pelanggaran atau kejahatan, baik kepada nasabah/manusia juga kepada Tuhan.

Di perbankan syariah prinsip dan asas, dikitari kegiatan yang bersifat keikhlasan untuk bekerja, dorongan spiritual keagamaan yang bersifat transendental dengan berharap ada sanksi, ganjaran dan pahala di hari kemudian. Sumber yang melahirkan asas-asas dan prinsip-prinsip universal tersebut, yakni "Quran dan hadis" berupa, prinsip dan asas keadilan, kesejahteraan, tolong menolong, keseimbangan dan prinsip operasional yakni prinsip kehati-hatian dan profesional

\section{B. Risiko Usaha/Kegiatan Perbankan Syariah Dan Tindak Pidana.}

Kegiatan/bisnis perbankan syariah merupakan Bagian penting dalam penyebaran ekonomi kesejahteraan sosial yang dinaungi keberkahan Tuhan (Allah Swt.). Secara teori Bank Syariah harus menghadapi risiko (misalnya sistem mudarabah). Secara teori risiko yang dimaksud, adalah keikhlasan investor ke pengelola dana (bank Syariah) untuk mengelola dana tersebut dengan segala risiko, yang harus ditanggung bersama. Artinya dana yang digunakan atau diinvestasikan mengalami kerugian, bukan karena kesengajaan tetapi secara alami, maka itu bagian yang harus terima lapang secara bersama tanpa meminta kerugian yang dialaminya . Konsep dan praktik risiko dalam perbankan syariah di Indonesia belum sepenuhnya berjalan. Praktik risiko bersama, harus penuh kehatihatian ini, dalam konteks alami dan non alami. Non alami artinya pihak perbankan 
yang telah menggunakan dana investor membuat akal-akalan seolah-olah terjadi musibah untuk mendapatkan /mengambil sisa dana dari proyek/usaha yang gagal tersebut.

\section{Zakat dalam Perbankan Syariah dan CSR pada perbankan konvensional}

Sebagai korporasi, secara tidak langsung telah, mempunyai tanggung jawab sosial sebagai bagian (kegiatan usaha) berupa tanggung jawab bernegara dan akan memulihkan keadaan sosial (pengalihan margin perbankan ke bantuan zakat) "corporate social responsibility" (CSR), kelebihan/fungsi zakat, yakni secara terus menerus seiring berkembangnya perbankan syariah.

Pada perbankan konvensional, lebih pada prinsip untuk meraih keuntungan dunia semata untuk sebagian orang, yang bekerja, Perbankan konvensional, tetap memiliki prinsip kehati-hatian dalam pengelolaan, menjauhi risiko yang menanam investasi dan atau mengeliminir segala risiko pihak2 yang berinvestasi dalam proses bisnis perbankan guna menjaga reputasi kepercayaan hanya bagi mereka terkait perbankan (meskipun Negara mensyaratkan setiap korporasi, wajib memulihkan dan perbaikan keadaan social dalam bentuk bantuan bantuan pemulihan social (CSR), sifatnya yang tidak permanen (kualitas dan kuantitas bantuan berdasarkan keuntungan).

\section{Sinergi tas DSN, DPS dan OJK}

Perihal hubungan OJK. Fungsi DSN dan DPS merupakan lembaga yang mengarahkan bank syariah untuk menerapkan prinsip-prinsip syariah dalam kegiatannya. DSN pada moral etik sedang DPS pada lembaga/institusi dan produk. Oleh karena itu, DSN dan DPS dapat memberikan teguran jika ada lembaga/produk ekonomi tertentu yang menyimpang dari hukum yang telah ditetapkan. Jika lembaga/produk yang bersangkutan tidak mengindahkan teguran yang diberikan, maka DSN mengusulkan kepada instansi yang berwenang untuk mengambil tindakan apabila peringatan tidak diindahkan. ${ }^{3}$ Sesuai dengan amanat UU No. 21 Tahun 2011. Karena amanat UU tersebut, maka kehadiran OJK wajib dan diperlukan. Oleh karena itu, komunikasi dan koordinasi antara OJK dengan DSN menjadi suatu hal yang harus dipenuhi.

Adanya rekomendasi DSN mengenai dugaan tindak pidana perbankan yang terjadi pada perbankan syariah merupakan pintu masuk dilakukannya penyelidikan dan penyidikan oleh penyidik OJK. Bukan berarti penyidik OJK

${ }^{3}$ Keputusan Dewan Pimpinan MUI No. Kep-754/MUI/II/1999 tentang Pembentukan Dewan Syariah Nasional MUI.

84 
baru bertindak apabila ada rekomendasi dari DSN mengingat kejahatan perbankan merupakan kejahatan yang dilakukan secara terstruktur dan sistematis.

Lembaga DSN pada perbankan syariah, sebatas berfungsi sebagai lembaga penjaga moral/etika personality dan organisasi/manajemen syariah sementara OJK selain sebagai pengawas juga berfungsi lembaga penegak hukum. Oleh karena itu harus ada sinergi tas kedua lembaga tersebut dalam mengungkap kejahatankejahatan yang terjadi pada perbankan syariah mengingat berbagai modus operandi yang dilakukan dalam kejahatan perbankan

Secara struktural dan sistem pengawasan pada bank syariah berbeda dengan bank konvensional. Pengawasan perbankan syariah mencakup dua hal, yaitu pertama pengawasan dari aspek keuangan, kepatuhan kepada perbankan secara umum, dan prinsip kehati-hatian bank. Kedua, pengawasan prinsip syariah dalam kegiatan operasional bank. Secara struktur kepengurusan bank syariah terdiri dari Dewan Komisaris dan Direksi dan wajib memiliki Dewan Pengawas Syariah yang berfungsi mengawasi kegiatan bank syariah. ${ }^{4}$

Perbankan syariah juga menghadapi risiko sebagaimana perbankan konvensional sehingga juga membutuhkan pengawasan yang efektif untuk menjamin stabilitas sistem secara keseluruhan. Perbankan syariah menghadapi credit risk lebih besar terkait masalah adverse selection, moral Hazar dan costly State verification. Begitu pun halnya dengan liquidity risk terkait cash flow yang lebih tidak terprediksi dan keterbatasan instrumen keuangan untuk menutup defisit. $^{5}$

\section{E. Otoritas Jasa Keuangan (OJK) Dan Kewenangan Penyidikan}

Secara teori dan legalitas hukum kehadiran lembaga OJK sebagai Salah satu lembaga yang ditunjuk khusus oleh undang-undang untuk melakukan penyidikan terhadap kejahatan perbankan. Berdasarkan Pasal 1 angka 1 Undang-UUOJK, bahwa OJK adalah lembaga yang independen dan bebas dari campur tangan pihak lain, yang mempunyai fungsi, tugas, dan wewenang pengaturan, pengawasan, pemeriksaan, dan penyidikan sebagaimana dimaksud dalam undang-undang ini.

Penyidikan merupakan salah satu tugas pengawasan OJK seperti yang disebut dalam Pasal 9 huruf c UU OJK yang berbunyi:

Untuk melaksanakan tugas pengawasan sebagaimana dimaksud dalam Pasal 6,

OJK mempunyai wewenang melakukan pengawasan, pemeriksaan, penyidikan,

perlindungan Konsumen, dan tindakan lain terhadap Lembaga Jasa Keuangan,

${ }^{4}$ Amiruddin K, "Perbankan Syariah dalam Perspektif Hukum", Jurnal Al-Risalah, Fakultas Syariah dan Hukum UIN Alauddin, Volume 11, No. 1 Mei 2011, h. 184.

${ }^{5}$ Yusuf Wibisono, "Politik Ekonomi UU Perbankan Syariah Peluang dan Tantangan Regulasi Industri Perbankan Syariah", Bisnis \& Birokrasi, Jurnal Ilmu Administrasi dan Organisasi, Vol. 16, No. 2, Mei-Agustus 2009, h. 108.

85 
pelaku, dan/atau penunjang kegiatan jasa keuangan sebagaimana dimaksud dalam peraturan perundang-undangan di sektor jasa keuangan."

Wewenang OJK dalam melakukan penyidikan ini juga dipertegas dalam Pasal 49 ayat (1) UU OJK:

Selain Pejabat Penyidik Kepolisian Negara Republik Indonesia, Pejabat Pegawai Negeri Sipil tertentu yang lingkup tugas dan tanggung jawabnya yang meliputi pengawasan sektor jasa keuangan di lingkungan OJK, diberi wewenang khusus sebagai penyidik sebagaimana dimaksud dalam Kitab Undang-Undang Hukum Acara Pidana."

Adapun wewenang Penyidik Pegawai Negeri Sipil (PPNS) yang dimaksud pada kejahatan perbankan antara lain adalah (Pasal 49 ayat [3] UU OJK):

1. memanggil, memeriksa, serta meminta keterangan dan barang bukti dari setiap orang yang disangka melakukan, atau sebagai saksi dalam tindak pidana di sektor jasa keuangan;

2. meminta keterangan dari bank tentang keadaan keuangan pihak yang diduga melakukan atau terlibat dalam pelanggaran terhadap peraturan perundang-undangan di sektor jasa keuangan;

3. memblokir rekening pada bank atau lembaga keuangan lain dari pihak yang diduga melakukan atau terlibat dalam tindak pidana di sektor jasa keuangan;

4. meminta bantuan ahli dalam rangka pelaksanaan tugas penyidikan tindak pidana di sektor jasa keuangan; dan

Sesuai dengan ketentuan Pasal 6 ayat (1) huruf b KUHAP, ketentuan penyidik PPNS diakui sebagai penyidik sesuai dengan undang-undang yang berlaku di mana PPNS tertentu diberi wewenang khusus oleh undang-undang. Bukan saja terhadap kejahatan perbankan di dalam negeri, menurut Pasal 47 ayat (1) huruf c UUOJK dapat melakukan pula bekerja sama dengan otoritas pengawas Lembaga Jasa Keuangan di negara lain serta organisasi internasional dan lembaga internasional lainnya dalam rangka pemeriksaan dan penyidikan serta pencegahan kejahatan di sektor keuangan. Tujuan kerja sama bantuan hukum timbal balik dalam perkara pidana untuk mempermudah proses penyidikan dalam rangka pembuktian perkara dalam persidangan khususnya bagi negara yang meminta bantuan hukum. ${ }^{6}$

Bantuan hukum tersebut juga berlaku sebaliknya. Wewenang OJK dalam hubungan internasional sebagaimana ditentukan dalam Pasal 47 ayat (4) UUOJK adalah melakukan kerja sama dan memberikan bantuan dalam rangka pemeriksaan dan penyidikan yang dilakukan oleh otoritas pengawas Lembaga

${ }^{6}$ M. Irwansyah Putra, “Peranan Otoritas Jasa Keuangan Dalam Melakukan Pengaturan Dan Pengawasan Terhadap Bank, Jurnal Hukum Ekonomi, Vol. II No. 1, Juni 2013, h. 7.

86 
Jasa Keuangan negara lain berdasarkan permintaan tertulis. Wewenang penyidikan ini tidak dimiliki oleh Bank Indonesia sebagai pengawas bank selama ini. Wewenang yang lebih luas dalam konteks pemeriksaan ini seperti wewenang aparat penegak hukum. OJK dapat bertindak lebih tegas lagi apabila menemukan pelanggaran/ penyelewengan dari hasil pemeriksaannya.

Namun diketahui pula, bahwa sebagaimana diuraikan di atas, industri perbankan adalah industri kepercayaan yang bersifat sistemis. Bagi institusi pengawas/ pemeriksa perbankan punya tugas dilihat dari dua sisi. Sisi penegakan ketentuan hukum yang disaat tertentu bersifat represif yang dapat memengaruhi kehidupan privacy nasabah dan institusi bank tersebut (Syariah), berupa adanya kerugian manajemen kerja dan tingkat kepercayaan kepada bank tersebut dapat menurun, bila menempuh jalur hukum tanpa kehati-hatian, mengoreksi kerahasiaan bank secara terbuka telanjang bulat. Artinya proses pemeriksaan dan atau sampai pada persidangan, tetap mendahulukan kaidah-kaidah pengelolaan bank, agar kerahasiaan tetap terjaga, sepanjang tidak ada indikasi kuat ada tindak pidana di dalamnya (penggelapan, penipuan (KUHPidana) pencucian uang UUTPK), pembocoran data rahasia (UU ITE).

Fungsi kaidah-kaidah kerahasiaan dalam kelola Bank, harus dijamin oleh hukum/UU, (perdata dan pidana) adalah dengan menjaga kepercayaan para pihak yang berjanji (bank dan nasabah) yang sepakati bersama dalam klausul dokumen perjanjian.

Dalam meningkatkan perbankan nasional (konvensional dan Syariah) agar terus tumbuh agar tetap sehat tidak akan pernah terjerat aspek pidana di dalamnya, maka harus punya strategi apabila menemukan kejahatan (tindak pidana) dan pelanggaran dalam kelolaannya, maka dengan cara atau ibarat menangkap ikan, jangan sampai airnya keruh, sulit/lama telacak pelanggaran hukumnya, dapat merusak habitat ikan-ikan lainnya. Hal ini diperlukan pula hubungan kehumasan dan media yang terjalin baik, media baiknya/seyogyanya menginfokan ke masyarakat bila pelaku tindak pidana dalam dunia perbankan, bila sudah terbukti salah oleh pengadilan. Inilah uniknya aparat penegak dan penegakan hukumnya pada perbankan yang berbeda dengan aparat penegak hukum lainnya. ${ }^{7}$

Dalam praktik spesifikasi penyidikan dalam kejahatan di bidang keuangan dilakukan oleh penyidik OJK, meskipun tidak mengurangi kewenangan penyidikan yang ada ditangan kepolisian. Ketentuan seperti ini sebelumnya hanya berlaku untuk kejahatan di pasar modal, sedangkan kejahatan di sektor keuangan

\footnotetext{
${ }^{7}$ Bambang Murdadi, "Otoritas Jasa Keuangan (OJK) Pengawas Lembaga Keuangan Baru yang Memiliki Kewenangan Penyidikan", Value Aded, Majalah Ekonomi dan Bisnis Universitas Muhammadiyah Semarang (UNIMUS), Vol. 8, No. 2, Maret-Agustus 2012, h. 35.
} 
lainnya merupakan kewenangan kepolisian. Tidak dimilikinya kewenangan penyidikan bagi pengawas bank mempengaruhi efektivitas dalam menjalankan tugas pengawasan bank. Sering kali pengawas "kewalahan" menghadapi pengurus bank yang tidak kooperatif dan nakal. Adanya kewenangan penyidikan yang dimiliki oleh OJK diharapkan penanganan seluruh kejahatan di sektor keuangan dapat dilakukan oleh satu institusi yaitu OJK. ${ }^{8}$

Kaitan penyidikan dalam aspek hukum pidana, tentunya tidaklah secara langsung, karena sebelumnya haruslah dapat dipahami, bahwa hubunganhubungan hukum dalam dunia perbankan adalah mengatur hak dan kewajiban keperdataan (perdata umum dan perdata dagang), sehingga memisahkan antara mana perbuatan/peristiwa perdata dan mana tindak/perbuatan/peristiwa/delik pidana. Memahami kejahatan perbankan yang lebih luas, memerlukan kajian, kesaksian, kejelian (profesionalitas dan intelektualitas) hukum yang cermat agar tidak terjadi kerugian, penzaliman salah satu pihak, karena salah menempatkan/memosisikan kedudukan seseorang atau dua pihak atau sebaliknya.

Negara dalam hal ini, yang memegang otoritas penyelidikan dan penyidikan tersebut, apakah benar ada tindak pidana di dalamnya, yang pada umumnya "mindset" masyarakat, bahwa pihak perbankanlah yang sebagai pembuat/pelaku, namun peluang orang/masyarakat mitra/nasabah dapat pula/bisa melakukan tindak pidana dalam hubungan dengan perbankan (syariah) seseorang atau sekelompok orang dengan cara merusak sistem keamanan simpanan nasabah, sehingga uang nasabah mengalir kepada orang yang berbuat jahat tersebut (KUHPidana, UUITE), sehingga pihak perbankan terkadang tidak mengetahuinya/luput, maka sebagai rasa tanggung jawab perbankan harus mengganti uang nasabah yang hilang (perdata) karena telah diikat suatu perjanjian, berupa perbankan menjamin keamanan dan kehilangan simpanan nasabah.

Begitu pun bila ditemukan orang dalam bank yang merusak sistem manajemen dalam rangka kejahatannya atau orang melibatkan orang dalam sehingga terwujud suatu kejahatan (delik pidana), maka Negara dan atau perbankan harus segera bertindak sebagai suatu delik umum bukan delik aduan untuk segera di usut untuk diberi sanksi pidana penjara pelakunya, meskipun orang dalam bank (segenap jajaran bawah sampai ke atas dapat dikenai sanksi pidana secara personal atau bersama-sama pasal 55 KUHPidana)

${ }^{8}$ Zulkarnain Sitompul, "Konsepsi dan Transformasi Otoritas Jasa Keuangan (Conception and Transformation Financial Services Authority), Jurnal Legislasi Indonesia, Vol. 9 No. 3. Oktober 2012, h. 356. 


\section{F. Organisasi, Struktur Pengelolaan Bank dan atau korporat (Konvensional dan Syariah) dalam perspektif Pembubaran Organisasi "Parse pro Toto"}

Kesalahan (tindak pidana) suatu oknum dalam suatu institusi perbankan, tidak dapat dibebankan kesalahan pada seluruh oknum struktur organisasi perbankan tersebut, maka beban sanksi hanya pada oknum atau oknum yang berbuat jahat tersebut, sedang organisasi/manajemen tidak dapat dibebani kesalahan atau tindak pidana secara institusional (korporat), meskipun oknum tersebut bagian dari manajemen struktur organisasi tersebut, artinya bank tetap berjalan, biarlah sanksi hukum berjalan kepada oknum palaku.

Bila suatu bank (syariah) berbuat kesalahan kejahatan dan ditemukan suatu indikasi kuat, yang dilakukan secara sistematis, terencana dan masif, dengan melibatkan semua struktur organisasi/manajemen bank tersebut, maka dapat dikategorikan tindak pidana korporasi, maka usaha, organisasi dan manajemen (perbankan), dapat dibubarkan serta menghukum oknum-oknum pelaku berdasarkan tingkat delik pidana yang dikerjakan masing-masing oknum, baik sendiri-sendiri maupun bersama-sama/turut serta ( Pasal 55 KUHPidana dan pasal-lainnya serta UU tindak pidana khusus lainnya)

\section{G. Ruang Dan Peluang Masuknya Aparat penyidik Polisi}

Diketahui bahwa dunia perbankan adalah industri jasa, wilayah privacy/menjaga kerahasiaan nasabah menjaga hubungan rahasia antara dua pihak (subyek hukum), sehingga beberapa pihak atau pakar berpendapat, persoalan perbankan tidak boleh ketahuan siapa pun (kecuali sistem/pemegang sistem dan nasabah/pemakai jasa).

Pendapat tersebut di atas, ada yang membenarkan secara absolut, ada pula tidak, dengan alasan bahwa, dalam industri kepercayaan (keamanan akan kehilangan uang/harta dan keamanan akan adanya simpanan jumlah dan nilainya tidak boleh diketahui orang lain). Namun bila terjadi sesuatu yang melanggar/bertentangan dengan dua (2) hal tersebut, maka orang/mitra/nasabah tersebut patut melaporkan ke pihak aparat hukum Negara (Kepolisian).

Pelibatan penyidik kepolisian tidak serta merta, karena industri perbankan memiliki otoritas tersendiri, spesifik, maka terlebih dahulu memfungsikan OJK,

Terkait ruang dan peluang secara teoretis terjadinya tindak pidana, seyogyanya tidak perlu terjadi karena ranah hukumnya bersifat privacy, kepercayaan dan keperdataan. Suatu sifat kesalahannya, umumnya berupa kerugian yang dialami satu pihak atau para pihak biasanya karena ke tidak sengaja, tidak berniat atau musibah yang tidak diharapkan dan penyelesaiannya tidak berakhir ke pertanggungjawaban pidana, tetapi lebih pada perdata (dalam sidang atau luar sidang). 
Sistem keamanan perbankan dalam rangka dalam rangka pengawasan Negara, terbentuknya institusi otoritas Jasa Keuangan (OJK) yang dibentuk dalam Untuk mengantisipasi perkembangan kejahatan-kejahatan perbankan tersebut, tentu dibutuhkan perangkat hukum dan salah satu solusinya adalah dibentuknya lembaga Otoritas Jasa Keuangan (OJK) sebagai amanah dari Undang-Undang Nomor 21 Tahun 2011 tentang Otoritas Jasa Keuangan (UUOJK) yang diundangkan tanggal 22 November 2011. Secara teoretis OJK memiliki kewenangan untuk mengawasi (right to control) berupa kewenangan untuk melakukan penyidikan (right to investigatif). Berdasarkan data dari OJK, lembaga pengawasan industri perbankan di Indonesia, diketahui sepanjang tahun 2013 menangani 619 kasus kejahatan perbankan tersebar di berbagai daerah di Indonesia. ${ }^{9}$

Meskipun masyarakat pemakai jasa dan kalangan perbankan mengetahui akan tugas, fungsi dan kewenangan OJK yang dalam tugasnya penindakan/penyidikan penindakan, penindakan yang dilakukan tidak serta merta karena melalui mekanisme izin Bank Indonesia sebagai pemegang kendali otoritas keuangan Negara. Hal mana aspek-aspek privacy atau kerahasiaan Bank, menjadi kendala lain menindak perbankan nakal, bila terjadi tindak pidana pada bank tersebut. Artinya penyidikan pada suatu bank hanya dapat dilakukan atas permintaan kepada pimpinan lembaga penyidikan (kepolisian atau kejaksaan)

Terkait praktik penyidikan tersebut, tentunya semua melalui proses pelaporan yang teliti, proses pelaporan sebagai bagian dari penyidikan dalam kasus melibatkan personal/oknum atau manajemen organisasi institusi perbankan tersebut, memerlukan cara-cara yang melibatkan keahlian pihak yang terkait perbankan ( akuntan, Dewan Syariah, penyidik ahli manajemen, keuangan dan pakar ITE terkait sistem teknologi ), sehingga, hanya pimpinan kepolisian, kejaksaan atau Hakim dapat meminta kepada pihak perbankan untuk membuka catatan/dokumen keuangan dan atau dokumen-dokumen perjanjian pihak-pihak yang terkait pelaporan atas diduga telah terjadi tindak pidana tersebut.

\section{H. Bentuk-Bentuk Kejahatan Dalam Perbankan Konvensional, Perbankan Syariah Dan Perbankan Pada Umumnya.}

Tindak pidana dalam dunia perbankan atau kejahatan perbankan, tidak hanya meliputi yang dilakukan individual orang dalam bank, tetapi juga di lakukan secara terorganisir, atau pelaku lebih satu orang melibatkan dalam bentuk kerja sama orang luar dan orang dalam untuk berbuat kejahatan. Salah satu modus dari

\footnotetext{
${ }^{9}$ Anonim, Jumat, 22 Agustus 2014, “OJK Tangani 619 Kasus Kejahatan Perbankan” http://www.hukumonline.com/berita/baca/It53f7754864477/ojk-tangani-619-kasus-kejahatanperbankan, diakses tanggal 9 Desember 2020.

90
} 
berbagai modus yang terjadi, antara lain, dengan cara meminjam kredit jumlah besar, meskipun si peminjam kredit (debitur) dan perbankan (kreditur) sadar bahwa tidak laik layak, tidak kredibel ( boleh jadi jaminan kreditur meragukan, tetapi orang dalam meloloskan saja untuk cairnya kredit), namun tetap dilakukan oleh para pihak karena kemungkinan dengan cara begitu, orang dalam dijanjikan uang (fee) jasa, yang pada gilirannya cairnya kredit tersebut, yang berangkutan melarikan diri ke Negara lain.

Hal lain, peluang yang bisa terjadi akal akalan dengan status bangkrut, hal mana yang bersangkutan/usaha yang bersangkutan masih terikat kewajibannya di perbankan, dengan meminta penetapan pengadilan sebagai usaha yang "kolaps"/bangkrut atau dinyatakan "pailit" (suatu lembaga kepailitan dalam hukum perdata. Meskipun dunia perbankan dalam hubungan hukum adalah keperdataan, namun oknum penyimpang/pembuat kejahatan perdata ,dapat dijerat oleh pidana.

Adapun penyimpangan hukum perdata yang terindikasi pidana oleh orang/mitra perbankan, biasanya dengan cara atau modus Terkait dengan berbagai cara yang dilakukan dengan akal-akalan untuk mengambil/ untuk memiliki uang nasabah yang dikelola perbankan tersebut, yakni dengan akal-akalan berbuat seolah-olah kebangkrutan karena uang yang dikelolanya, dibuat seolah ada musibah yang bukan alamiah oleh alam (usaha peternakan dimatikan dalam jumlah besar, yang seolah-oleh penyakit bencana, usaha perkebunan yang seolaholah besar dimatikan lalu dinyatakan terjangkit hama penyakit). Olehnya dengan berbagai cara dan akal pengelola bank dapat mengambil/menilap uang/simpanan nasabah atau sebaliknya nasabah debiturlah yang melakukan penipuan terhadap perbankan atau kejahatan itu terjadi karena persekongkolan semua pihak, hingga cairnya kredit/pinjaman perbankan tersebut.

Modus kebangkrutan, yang sesungguhnya bukan bencana, bukan pula krisis keuangan global dan sebagainya. Maka pelaku atau pihak-pihak terjadi biasanya melarikan diri dan melarikan uang ke suatu tempat/Negara dan menjadi warga Negara lain. Adapun salah satu bentuk kejahatan perbankan yang sifatnya personal yang biasanya terjadi pada sistem transfer (pemakaian kartu elektronika/kartu ATM sebagai kambing hitam) sebab dugaan kedua belah, baik pihak orang dalam bank maupun menyalahkan orang luar sebagai nasabah pemilik kartu. Adapun pendekatan pidana, harus diduga awal , bahwa kedua patut, samasama memungkinkan untuk berbuat Kejahatan perbankan.

Adapun kasus yang paling merugikan masyarakat umum "publik" kasus Dana BLBI dan Kasus Bank Century beberapa tahun lalu, yang mana Negara harus mengganti kerugian tersebut, meskipun masyarakat tidak merasakan langsung dan 
seketika dampak perbuatan tersebut, tetapi beban rakyat dan Negara secara perlahan dengan berbagai cara politik maupun non politik mengembalikan kondisi Keuangan Negara dan kepercayaan publik (Trust).

Bentuk-bentuk kejahatan pada perbankan konvensional dan atau perbankan syariah, seperti yang pernah dikemukakan oleh, Endang Kussulanjari Tri Subari, (Deputi Komisioner Pengawas Perbankan II), bahwa ada beberapa titik rawan yang patut diwaspadai nasabah dan bank dalam tindak pidana perbankan di antaranya: penghimpunan dana tanpa izin, kegiatan operasional bank, meminta tip atau imbalan, persetujuan kredit dengan tidak jujur, sistem validasi yang keliru, hingga kekeliruan penyimpangan data untuk dana yang tersimpan di bank. ${ }^{10}$

Tindak pidana/kejahatan perbankan biasanya pelakunya hanya orang dalam, namun banyak juga melibatkan orang luar (persekongkolan/kolusi) misalnya dalam penyaluran kredit (kredit fiktif). Atau pihak luar bank yang secara sendiri tanpa melibatkan orang dalam berbuat fiktif (orang, kegiatan dan dokumen), namun hal ini jarang terjadi karena karena dilakukan secara canggih, umumnya pelaku setelah melakukan, umumnya melarikan diri antar Negara.

Umumnya terjadinya kredit fiktif tersebut, karena lemahnya pengawasan internal bank, serta unsur individu-individu yang memperkaya diri, orang lain atau keluarga ,dengan melanggar hukum (tindak pidana/kejahatan perbankan) dengan cara, dimana pegawai bank tersebut melakukan kolusi dengan nasabah dari luar perbankan tersebut. Dengan kata lain kolusi pada bank, pihak bank yang menjadi objek penipuan dan atau penggelapan, modus, cara dan gerakan pelakunya kadang semakin canggih dan bervariasi, biasanya salah satu pihak yang berkolusi adalah oknum bank.

fraud dan criminal (kejahatan perbankan) yang terjadi tersebut, tidak hanya berpotensi merugikan bank secara finansial, tetapi juga tingkat kepercayaan akan berkurang dan cepat atau lambat menimbulkan tingkat reputasi yang menurun. ${ }^{11}$ Kejahatan dalam jasa keuangan, tidak saja dalam dunia perbankan, tetapi juga terjadi sektor non bank (lembaga-lembaga pengumpul, simpan pinjam, dan sebagainya),

Bentuk-bentuk kejahatan itu, antara lain, pemalsuan dokumen bank, penerbitan $L / C$ fiktif, pengucuran kredit kepada perusahaan fiktif, mendirikan bank gelap/usaha-usaha yang menampung uang masyarakat dengan iming-iming

10 Fajar Sulaiman, 04 September 2014," OJK: Ada Titik-titik Rawan dalam Tindak Pidana Perbankan”, $\quad$ http://wartaekonomi.co.id/berita34690/ojk-ada-titiktitik-rawan-dalam-tindakpidana-perbankan.html, diakses tanggal 9 Desember 2020.

11 Hamsir, "Moral Hazard Tindak Pidana Kredit Fiktif Bank Syariah Mandiri", Jurnal Jurisprudentie, Jurusan Ilmu Hukum Fakultas Syariah dan Hukum UIN Alauddin Makassar, Vol. 1, No. 1, Juni 2014, h. 69.

92 
bunga tinggi, membuat cicilan kredit bermasalah dan perusahaan yang bangkrut dengan segala usaha meminta yang dilandasi niat keuntungan bila meminta untuk dinyatakan pailit, pengajuan kredit dengan jaminan bodong, tindak kejahatan melalui internet bangking, kejahatan melalui pemalsuan surat berharga (obligasi dan reksadana) dan valuta yang notabene tidak saja melanggar ketentuan hukum nasional, ke semua jenis perbuatan tersebut, pada hakikatnya juga melanggar prinsip-prinsip syariah.

Adapun kasus yang pernah terjadi pada perbankan syariah salah satunya, adalah kejahatan yang terjadi pada di salah bank syariah adalah kredit fiktif pada Bank Syariah Mandiri (BSM) Cabang Bogor.

\section{PENUTUP}

\section{A. Kesimpulan}

Aspek-aspek tindak pidana pada perbankan syariah dalam melihat dan mengamati realitas, peluang dan tantangan. Diyakini bahwa, perbankan bagian dari suatu usaha/industri, sama dengan perbankan lainnya, yang ternyata dalam realitas dapat juga terjadi tindak pidana, beberapa kasus yang terjadi, pelaku/ oknum pelakunya umumnya orang dalam , adapun bank syariah pada umumnya, atau salah satu dari beberapa bank syariah ada, secara terstruktur (kejahatan korporasi) belum pernah ditemukan ada tindak pidana yang dilakukan secara sistematis, terencana dan sistematis. Kasus-kasus yang ada. lebih pada etika individu (moral hazard). Olehnya peran masyarakat senantiasa memantau dan melaporkan terlebih dahulu pada pimpinan/manajemen agar dapat diselesaikan baik, tanpa menimbulkan riak dan gejolak yang berlebihan (bila ingin menangkap ikan di kolam, hendaknya isi/air kolamnya tidak membuat keruh atau kekisruhan yang berlebihan).

Namun demikian, bila unsur manajemen bank tersebut, sulit menemukan sumber kasusnya, maka jalan penyelesaiannya haruslah melibatkan berbagai pihak (OJK, DSN, DPS atau aparat hukum/penyidik). Namun tindakan tersebut sebelum terlebih jauh, tentunya masih berharap pada manajemen bank syariah tersebut untuk menyelesaikannya dengan catatan tidak menimbulkan kerugian pihak yang terkenai/terimbas kejahatan tersebut. Peluang terjadinya tindak pidana, tetap ada seiring dengan perkembangan manusia ke arah materialistis, hedonis, juga peluang itu ada bila kerja sama akal-akalan/kongkalikong ( orang dalam dan orang luar dan atau dengan aparat hukum) atau dengan pihak lain yang terkait, sehingga merugikan pihak lainnya. 


\section{B. Saran}

Perbankan syariah agar terhindar dari jerat hukum (tindak pidana/kejahatan perbankan),beberapa saran sederhana antara lain, yakni, SDM senantiasa diperkuat dengan iman dan moral. Senantiasa memperbaharui sistem teknologi. Patuh dan taat dengan rambu-rambu hukum dalam lalu lintas perbankan syariah pada khususnya dan rambu-rambu (regulasi-regulasi) perbankan pada umumnya. Optimalisasi kerja sama, DSN, DPS, UJK dan aparat kepolisian dan kejaksaan. 


\section{DAFTAR PUSTAKA}

Amiruddin K. "Perbankan Syariah dalam Perspektif Hukum", Jurnal Al-Risalah, Fakultas Syariah dan Hukum UIN Alauddin, Volume 11, No. 1 Mei 2011.

Anonim, Sabtu 20 Juli 2002, “OJK Akan Diberi Kewenangan Menyidik", tersedia di website http://www.hukumonline.com/berita/baca/ hol6051/ojk-akan-diberi-kewenangan-menyidik, diakses tanggal 9 Desember 2020.

Jumat, 22 Agustus 2014, "OJK Tangani 619 Kasus Kejahatan Perbankan" http://www.hukumonline.com/berita/baca/lt53f7754864477/ojktangani-619-kasus-kejahatan-perbankan, diakses tanggal 9 Desember 2020.

Bambang Murdadi. "Otoritas Jasa Keuangan (OJK) Pengawas Lembaga Keuangan Baru Yang Memiliki Kewenangan Penyidikan”, Value Aded, Majalah Ekonomi dan Bisnis Universitas Muhammadiyah Semarang (UNIMUS), Vol. 8, No. 2, Maret 2012, Agustus 2012.

Fajar Sulaiman. 04 September 2014,” OJK: Ada Titik-titik Rawan dalam Tindak Pidana Perbankan", http://wartaekonomi.co.id/berita34690/ojk-adatitiktitik-rawan-dalam-tindak-pidana-perbankan.html, diakses tanggal 9 Desember 2020.

Hamsir. "Moral Hazard Tindak Pidana Kredit Fiktif Bank Syariah Mandiri", Jurnal Jurisprudentie, Jurusan Ilmu Hukum Fakultas Syariah dan Hukum UIN Alauddin Makassar, Vol. 1, No. 1, Juni 2014.

M. Irwansyah Putra. "Peranan Otoritas Jasa Keuangan Dalam Melakukan Pengaturan Dan Pengawasan Terhadap Bank, Transparency, Jurnal Hukum Ekonomi, Vol. II No. 1, Juni 2013.

Wahyu Wiradinata. "Masalah Penyidik Dalam Tindak Pidana Jasa Keuangan Di Indonesia (Investigate Problem In Crime Financial Services In Indonesia)", Jurnal Legislasi Indonesia, Vol. 9 No. 3. Oktober 2012.

Yury Petrovich Garmaev. "Features of Combating Crimes in The Bangking Sector in The Russian Federation and in China" European Scientific Journal, Vol.10, No.10, April 2014.

Yusuf Wibisono, "Politik Ekonomi UU Perbankan Syariah Peluang dan Tantangan Regulasi Industri Perbankan Syariah, Bisnis \& Birokrasi, Jurnal Ilmu Administrasi dan Organisasi, Vol. 16, No. 2, Mei-Agustus 2009.

Zulkarnain Sitompul, "Tindak Pidana Perbankan dan Pencucian Uang (Money Laundering)," Reformasi Hukum, Vol. VII No.2 Juli-Desember 2004.

, "Konsepsi dan Transformasi Otoritas Jasa Keuangan (Conception and Transformation Financial Services Authority), Jurnal Legislasi Indonesia, Vol. 9 No. 3. Oktober 2012

Media On Line, Tribun Nasional, Desember, 2020 
Tingkat Kepercayaan meraih upaya, pasca kasus kejahatan perbankan, Diskusi Virtual. Purbaya, Desember 2020. 